\title{
Covid - 19 Sürecinde Yaygınlaşan Uzaktan Eğitimin Üniversite Öğrencilerinin Yenilikçi Davranış Eğilimleri İle İlişkisinde Örgütsel Adalet Algısının Aracılık Rolü: Bir Araştırma Edip ÖRÜCÜ 1, PInar KURT 2 , Itır HASIRCI ${ }^{3}$
}

\begin{abstract}
Özet
Bu araștırmanın amacı Covid-19 sürecinde üniversite öğrencilerinin uzaktan eğitim ile yenilikçi davranış ilișkisinde örgütsel adaletin aracılık etkisinin tespit edilmesidir. Araștırmanın evrenini, Bandırma Onyedi Eylül Üniversitesinde ögrrenim gören 15.721 öğrenci, örneklemini ise 393 öğrenci oluşturmaktadır. Araştırmada veri toplama yöntemi olarak anket uygulaması gerçekleştirilmiştir. Anketlerden elde edilen verilerle frekans analizi, güvenilirlik analizi, normallik testi, keş̧fedici faktör analizi, korelasyon analizi ve hiyerarşik regresyon analizi yapılmıştır. Araştırmanın sonucunda Covid-19 pandemi sürecinde üniversite öğrencilerinin uzaktan eğitime bakış açıları ile yenilikçi davranış eğilimleri arasında anlamlı bir ilişski olduğu ve bu ilişkide örgütsel adaletin tam aracılık etkisinin bulunduğu sonucuna varılmıştır. Araştırmanın konusu ile ilgili literatürde herhangi bir çalışmaya rastlanılmadığından bu çalışmanın alan yazına katkıda bulunması beklenmektedir.
\end{abstract}

Anahtar kelimeler: Uzaktan Eğitim, Örgütsel Adalet Algısı, Yenilikçi Davranış Eğilimleri, Covid-19

Jel Kodu: I21, M54, 039

\section{The Mediating Role Of Organizational Justice Perception In The Relationship of Distance Learning With Innovative Behaviour Trends Of University Students That Have Become Widespread In The Covid - 19 Process: A Research}

Abstract

The aim of this research is to determine the mediating effect of organizational justice in the relationship between distance learning and innovative behavior of university students in the Covid-19 process. 15,721 students studying at Bandirma Onyedi Eylül University and 393 students constitute the universe of the study. Survey application was carried out as data collection method in the research. Frequency analysis, reliability analysis, normality test, discoverer factor analysis, correlation analysis and hierarchical regression analysis were performed with the data obtained from the surveys. As a result of the study, it was concluded that during the Covid-19 Pandemic, there was a significant relationship between university students ' perspectives on distance learning and innovative behavior trends, and organizational justice had a full-mediated effect in this relationship. Since no studies have been found in the literature related to the subject of the study, it is expected that this study will contribute to the literature.

Keywords: Distance Learning, Organizational Justice, Innovative Behaviour, Covid-19

Jel Codes: I21, M54, 039

ATIF ÖNERİsİ (APA): Örücü, E. Kurt, P., Hasırcı, I., (2022). Covid-19 Sürecinde Yaygınlaşan Uzaktan Eğitimin Üniversite Öğrencilerinin Yenilikçi Davranış Eğilimleri İle İlişkisinde Örgütsel Adalet Algısının Aracılık Rolü. İzmir Íktisat Dergisi. 37(2). 387-405. Doi: 10.24988/ije.889212

1 Prof. Dr., Bandırma Onyedi Eylül Üniversitesi, İktisadi ve İdari Bilimler Fakültesi, Bandırma,

EMAIL: eorucu@bandirma.edu.tr ORCID:0000-0002-3301-7496

2 Öğr. Gör., Bandırma Onyedi Eylül Üniversitesi, Sağlık Hizmetleri Meslek Yüksekokulu, Bandırma,

EMAIL: pkurt@bandirma.edu.tr ORCID:0000-0001-6870-4248

3 İşletme Doktora Öğrencisi, Bandırma Onyedi Eylül Üniversitesi, Sosyal Bilimler Enstitüsü, Bandırma,

EMAIL: itir8686@gmail.com ORCID:0000-0002-5449-2640 


\section{GİRIş}

COVID-19 olarak bilinen yeni tip korona virüs (SARS-CoV-2), ilk olarak Aralık 2019'da Çin'in Wuhan kentinde ortaya çıkan bulaşıcı bir enfeksiyondur. Hızlı bulaşma özelliği gösteren bu virüs, kısa bir süre içerisinde tüm dünyaya yayılmıştır. Bu bağlamda salgına karşı mücadelede pek çok ülkede; okulların, üniversitelerin ve diğer eğitim kurumlarının geçici süre kapatılmasına karar verilmiş ve geleneksel (yüz yüze) eğitim modeli yerine uzaktan eğitim modeli benimsenmek zorunda kalınmıştır. Türkiye'de de ilk vaka görüldükten sonra (11 Mart 2020) Sağlık Bakanlığının önerisi ile okullar ve üniversiteler geçici olarak kapatılmıştır (Keskin ve Özer Kaya, 2020: 64). 8 milyon 76 bin 615 öğrencisi ve 177435 akademik personeli olan Yükseköğretim Kurumu da salgın sürecini ve krizi yönetebilmek adına 2019-2020 eğitim-öğretim bahar yılında yüz yüze eğitime ara verme kararı almış ve uzaktan eğitim modeline geçiş yapılmıştır.

Uzaktan eğitim, yüz yüze eğitimin sınırlılıkları nedeniyle sınıf içerisinde etkinliklerin yürütülme imkânının olmadığı durumlarda, iletişimin ve etkileşimin özel olarak hazırlanan ortamlar yoluyla sağlanmasıdır. Uzaktan eğitimin öğrenciler için sosyolojik, psikolojik, mali ve kültürel açıdan birçok avantajı olduğu gibi dezavantajları da vardır (Odabaş, 2003: 31). Mekân, yer sorunu olmadan eğitim ortamı oluşturulması, ekonomik olması, teknoloji ile birlikte eğitim etkinliklerinin zenginleștirilmesi avantajları arasındadır. Uzaktan eğitim sisteminin geliştirilmesi için zamana ihtiyaç olması, öğrencilerin uzaktan eğitim programlarını kullanabilmesinde gerek bilgisayar gerekse programların kullanımında yeterli düzeyde bilgiye ulaşamaması, sistemsel aksaklıklar, uzun süre bilgisayar, telefon ve tablet gibi cihazların kullanımı ile yaşanan problemler ise uzaktan eğitim sisteminin dezavantajlarını oluşturmaktadır.

COVID-19 sürecinde öğrencilerin gerek mesleki bilgi edinebilmeleri, gerekse eleştirel düşünebilmeleri açısından uzaktan eğitimin dezavantajları etkili olmuştur. Üniversite öğrencilerinin uzaktan eğitime karşı tutumlarının olumlu olması ve bu durumun yenilikçi davranış eğilimlerini olumlu etkilemesi arzu edilen bir durumdur. Bireylerin adalet algılarının onların birçok tutum ve davranışları üzerinde önemli etkileri olabileceği konusunda araştırmalar yapılmıştır. Adalet algısını olumsuz etkileyen faktörlerin varlığı halinde tutum ve davranışların da olumsuz etkileneceği beklenir. Ülkenin geleceği olarak tanımlanan öğrencilerin, yenilikçi davranmalarını destekleyecek sistemlerin, olumsuz adalet algısı ortamlarında başarılı olması beklenemez. Küresel salgın nedeniyle uygulamaya giren uzaktan eğitime karşı öğrencilerin tutumları ve yenilikçi davranış eğilimleri üzerindeki etkisini belirlemek bu çalışmanın temel amacıdır. Çalışmanın temel gerekçesi, ülke kalkınmasında gençlerin yenilikçi davranışlarının geliştirilmesine duyulan ihtiyaçtır. $\mathrm{Bu}$ ihtiyacın giderilebilmesi açısından uygulanan eğitim modellerine karşı tutumların rolü yadsınamaz. Çalışmanın önemi, yüz yüze eğitime ara verilmek zorunda kalınması nedeniyle uygulanan uzaktan eğitim modeline karşı tutumlar ve adalet algısının birlikte yenilikçi davranışlar üzerindeki etkisini araştıran ender çalışmalardan biri olmasıdır.

Dolayısıyla bu araştırmada, üniversite öğrencilerinde uzaktan eğitim ile yenilikçi davranış arasında bir ilişki olup olmadığı tespit edilecektir. Bu ilişkide örgütsel adaletin rolünün belirlenmesi ile literatüre yeni bir bakıș açısı kazandırmak hedeflenmiştir. Yapılan literatür taramasında COVID-19 sürecinde öğrencilerin uzaktan eğitim ile ilgili görüşleri doğrultusunda araştırmaların yapılmış olduğu (Durak ve diğerleri, 2020; Genç ve Gümrükçüoğlu, 2020) ancak üniversite öğrencilerinin yenilikçi davranış eğilimleri ve örgütsel adalet algıları ile ilgili çalışmaya rastlanmamıştır. Bu sebeple bu araştırma geleneksel yöntemlerle eğitim görmeye alışmış öğrenciler ve geleneksel yöntemlerle eğitim vermeye alışmış akademisyenler açısından web tabanlı modelin nasıl karşılandığını açıklayacaktır. Bu bağlamda araştırmamızın alan yazına katkıda bulunacağı düşünülmektedir. 


\section{KAVRAMSAL ÇERÇEVE}

\subsection{Uzaktan Eğitim}

Günümüzde eğitim ihtiyaçlarında yaşanan artış uzaktan eğitimi önemli bir alternatif olarak karşımıza çıkarmaktadır. Uzaktan eğitim, eğitim ve öğretim problemlerine alternatif olarak geliştirilen, eğitmen ve öğrenciler arasında etkileşim ortamının sağlandığı, sanal sınıflarda yapılır (Özbay, 2015: 385). Banar ve Fırat'a göre uzaktan eğitim, geleneksel yapıdaki eğitim sisteminde ortaya çıkan sınırlı durumlar nedeniyle, yüz yüze eğitimin mümkün olmadığı durumlarda belirli merkezlerden yönetimi sağlanan ve öğrencilerin kendi özel araçları ile katılım sağladığı bir sistemdir (Banar ve Fırat, 2015: 19). Uzaktan eğitim ile ilgili yükseköğretim düzeyine kadar farklı modeller geliştirilmiştir. Önceleri mektup ile bireylere hitap eden bu eğitim modeli daha sonra televizyon ve internet aracılığıyla yaygınlaşmaya başlamıştır. Sonrasında artan eğitim ihtiyacını karşılayan önemli bir etmen haline gelmiştir (Bakioğlu ve Çevik, 2020: 120).

Bilgi çağında zaman ve mekân fark etmeksizin, düşük maliyetle, internet aracılığıyla öğrenmeyi mümkün kılmak bilginin daha geniş kitlelere yayılmasına olanak tanımaktadır (Dikmen ve Bahçeci, 2020: 88). Dolayısıyla günümüz pandemi şartlarında örgün eğitimi destekleyen e-öğrenme giderek daha önemli hale gelmektedir (Hebebci vd., 2020: 277). Uzaktan eğitim, öğrencilere kendi kendilerine öğrenme olanaklarının tanındığı, geleneksel eğitim sistemine göre daha esnek bir yapıya sahip olan ve kendi koşullarına ayak uydurabilecek bir sistemdir (Kürtüncü ve Kurt, 2020: 71). Uzaktan eğitim aracılığıyla eğitim götürmekte sıkıntı yaşanılan ortamlara rahat bir şekilde hizmet sağlanmakta ve geniş kitlelere ulaşılmaktadır (Bayram vd., 2019: 338).

Bilgi ihtiyacının giderek arttığı dünyada bilgilerin saklanması, derlenmesi, işlenmesi için bilgisayarlar aracı görev üstlenmektedirler. Bunun nedeni kişilerin bilgi yığınlarını kontrol etme ihtiyacı duymaları ve bunu yönetmek istemeleridir. Temel işlevi bu hususlardan ibaret olan bilgisayarların eğitim-öğretim faaliyetlerinde kullanımı da giderek yaygınlaşmaktadır. Uzaktan eğitim aracılığıyla akademik kurumlar hem fiziksel yüzünü değiștirmiş hem de öğrenciler ev ortamı rahatlı̆̆ından ayrılmadan eğitim faaliyetlerine devam etme fırsatı yakalamışlardır. Kapasitesi yüksek olan donanımlar ve taşınabilir bilgisayarlar kitapların, internet üzerinden oluşturulan çevrimiçi sınıflar da üniversitelerin yerini almıştır. Bu faaliyetler vasıtasıyla binlerce öğrenci ve eğitmen kilometrelerce uzaktan birbirleriyle sesli ve görüntülü iletişim kurmaktadırlar (İşman, 2011: 55). Negüs'e göre uzaktan eğitim üç adımdan oluşmaktadır (Negüs, 2016: 8). İlk adım olan mektupla öğretim 19. yy ile 20. yy arasında basılı materyaller üzerinde yerini almıştır. Etkinlikler eğitmene posta yoluyla gönderilmiștir. İkinci adımda 70'li yıllarda basılı materyallerle birlikte radyo, TV, teyp, kaset ile devamlılı göstermiştir. Üçüncü adım ise 80’li yıllarda başlayan uydu teknolojilerinden ibarettir. Ancak gelişen telekomünikasyon teknolojileri ve internet ile uzaktan eğitim ortamı büyük bir değiş̧im yaşamıştır.

E-öğretim kavramı iki yolla gerçekleștirilmektedir. Bunlar (Karadağ ve Yücel, 2020: 187);

-Öğrencilerin kişisel bilgisayarları başında kendi kendilerine eğitim almaları olarak tanımlanan asenkron,

-Belli bir zaman dilimi içerisinde bir grup öğrenci ve eğitmenin sanal bir sınıfta buluşmaları olarak tanımlanan senkron şeklinde ifade edilebilir.

Uzaktan eğitimin belli başlı yararları mevcuttur. Öncelikli olarak bu sistem öğrenci merkezli bir yapıdır, kişilere fırsat eşitliği tanımaktadır ve eğitime ulaşırken coğrafi engellerin kaldırılmasını sağlar. Öğrenci kendi hızında öğrenme imkânları bulur, bilgiye kolay bir şekilde ulaşabilir, barınma ve ulaşım maliyetlerinin yükü ortadan kalkar, zaman ve mekân gözetmeksizin istediği an derslere erişebilir. Koç (2015), çağdaş eğitim uygulamaları sayesinde eğitime katma değer katıldığını ve verimliliğin yükseldiğini belirtmektedir (Koç, 2015: 50). Covid 19 pandemisi nedeniyle tercih oranı 
yükselen bu eğitim sistemi bir taraftan öğrencileri bir taraftan da eğitimi veren akademisyenleri etkilemiş ve iki tarafı da şartlara ayak uymak zorunda bırakmıştır. Bu yeni sistemle ilk defa karşılașan iki taraf da belirli zorluklarla karşılașmıştır (Kurnaz ve Serçemeli, 2020: 278).

\subsection{Yenilikçi Davranış}

Yenilik literatürde, yeni ve özgün olanı ifade eden bir kavram şeklinde karşımıza çıkmaktadır. Plessis (2007) yeniliği, işletmelerin daha iyi çıktılar elde etmek ve pazarda rekabet firsatları yakalamak için yeni fikirler üretmesi şeklinde tanımlamaktadır (Plessis, 2007: 24). Sweeney ise yenilik kavramını örgüt içerisindeki bir uygulamada, süreçte, örgütün yapısında ve çıktılarda olumlu neticeler yaratan değişikliklerin tümü șeklinde tanımlamaktadır (Sweeney, 2016: 171). Yenilik için yalnızca özgün fikirleri içeren bir kavram olduğu düşüncesi yeterli olmamaktadır. Bu özgün fikirler geliştirilip, yayılıp, uyarlandığında yenilik kavramı anlam kazanmaktadır (Damanpour, 1991: 571). Goswami ve Mathew yeniliği daha geniş bir çerçevede farklı tanımlarla ele almıştır (Goswami ve Mathew, 2005: 378). Bu tanımlar aşağıdaki gibidir;

-Olaylar ve olgular arasında yeni ilişkiler geliştirmek,

-Mevcut pazardaki gelişmeleri takip etmek,

-Yaşanan gelişmeleri takibe alarak, bu doğrultuda değişimleri gerçekleştirmek,

-Her türlü konuya yeni bir bakış açısıyla bakıp, eski kavramlarla farklı kombinasyonlar üretmek,

-Yenilikçi çalışanları ve liderleri örgüte çekmek, problemlere farklı bakış açısıyla yaklaşabilmek.

Katma değer yaratmak olarak tanımlanan yenilik kavramı, örgütsel bağlamda incelendiğinde yeniliğin örgütün performansına katma değer sağlaması olarak açıklanabilir. Bir fikir pratik maliyetle ve güvenilir şekilde ortaya koyulduğunda yenilikten söz edilebilir (Senge, 2000: 80). Yenilikçi davranış kavramı ise, farklı fikirlerin yaratılması, gelişimi, uygulanması, tanımlanması gibi süreçleri ele almaktadır (Thurlings vd., 2015: 455). Yenilikçi davranışı savunan bireylerin, durumları farklı boyutlardan değerlendirdiği, bu değerlendirme sonrasında en doğru çıkarımları yaptığı, bu çıkarımları çalışma arkadaşları ile paylaştığı ve kalıcı olması için emek verdiği belirtilebilir (Hasırcl, 2020: 55).

Örgütlerin başarılarını devam ettirebilmeleri için yeni fikirler ortaya koymaları, bu fikirleri uygulamaları ve değişen çevre şartlarına uyum sağlamaları gerekmektedir. Eğitim ile ilgili örgütler de değişen çevre koşullarına göre kendilerini yapılandırıp, iyi sonuçlar elde edebilir, diğer okullarla rekabet sağlayabilir ve öğrencileri de değişen dünyanın şartlarına alıştırabilirler. Bu durumda akademisyenler ve yöneticiler merkezi politikaların getirdiği yenilikleri uygulamak zorundadırlar. Eğitim sisteminde reform gerçekleştirmek için akademisyenlerin ve yöneticilerin değişimleri ve yenilikleri kabullenip, yaymaları dolayısıyla yenilikçi davranış göstermeleri gerekmektedir. Okullarda eğitimcilerin yenilikçi davranışlarının önem arz etmesinin üç temel nedeni bulunmaktadır. Bunlar;

-Yenilikçi davranış ile bireyler değişen dünyaya hızlı ayak uydurmak zorundadırlar,

-Eğitim - öğretim ile ortaya çıkan teknolojik yenilikler yenilikçi davranışı zorunlu kılmaktadır,

-Diğer toplumlar ile rekabet edebilmek adına eğitimcilerin yenilikçi davranış anlamında örnek teşkil etmeleri gerekmektedir.

Yenilikçi davranış kavramı grupsal ve bireysel olmak üzere iki başlık altında incelenebilmektedir. Grupsal davranış, farklı düşüncelerin grup içinde değerlendirilip, gerekli görüldügü durumlarda düzenlenmesi ve uygulanmasıdır. Bireysel davranış da kişilerin yenilikleri hayata geçirme istekleridir (Özçer, 2005: 26). Bireysel yenilikçilik kişilerin yenilikleri kabullenmesi ve uygulamaya çaba göstermeleri ile ilgili bir kavram olduğu için 5 grupta kategorize edilmektedir (Şentürk ve 
diğerleri, 2016: 186). Bunlar; öncüller, yenilikçiler, sorgulayanlar, kuşku duyanlar ve gelenekçiler şeklinde açıklanabilir. Yenilikçi grup yeniliği ilk olarak benimseyen kişilerden oluşmaktadır. Öncül grup, yeniliği erken benimseyip, çevrelerindeki kişilere yenilik ile ilgili bilgi verenlerdir. Sorgulayanlar, yeniliklere ve değişimlere karşı daima temkinli yaklaşan gruptur. Kuşku duyanlar, yeniliklere şüphe ile yaklaşan gruptur. Gelenekçi grup ise yeniliklere önyargı ile yaklaşan ve en son aşamada kabul eden kişilerden meydana gelmektedir. Eğitimcilerin bireysel yenilikçilik düşünceleri ile ilgili literatürde yer alan çalışmalara bakıldığında çoğunluğun sorgulayanlar grubunda bulunduğu görülmektedir (Akça ve Şakar, 2017: 36). Yüksek düzeyde yenilikçi davranış sergileyen akademisyenlerin olduğunu iddia eden çalışmalarda bireysel yenilikçilik seviyesinin üniversite mezuniyet puanına göre farklılaştığı, akademisyenlerin bireysel yenilikçilik seviyelerinin de unvanlarına göre farklılık gösterdiği görülmektedir (Demircioğlu vd., 2016: 1130).

Eğitimcilerin yenilikçi davranışları, değişen çevre koşullarına ayak uydururken, bilgi toplumlarının ilerlemesinde ve teknolojik açıdan ilerlemede önem arz etmektedir. Üniversitelerin değişim ve gelişim hızları toplumdan geri kaldığında kendi içlerinde gerilime sebep olmaktadır (Schlechty, 2014: 55). Bu sebeple eğitimcilerin yenilikçi davranış göstermeleri oldukça önemlidir. Amabile 'nin (1988) sistem teorisi yaklaşımı yenilikçi davranış sürecini, örgütlerin farklı departmanlarında çalışan iş görenlerin yeni bir düşünceyi pratiğe dökebilmek adına bir araya gelerek çalışmaları şeklinde açıklamaktadır (Amabile, 1988: 136). Bu sistemde yenilikçi davranış oluşurken örgütte bulunan her iş görenin yaratıcılığını ve inovatif fikirlerini ortaya koyması önem taşımaktadır. Üniversiteler bir açık sistem olarak ele alındığında yenilik düşüncesine etki edebilecek pek çok unsurdan söz edilebilir. Ancak eğitim ve öğretimden birinci derecede mesul olan akademisyenlerin bu anlamdaki katkısı daha fazla olacaktır.

\section{3 Örgütsel Adalet Algısı}

İlk kez 1987 yılında Greenberg tarafından literatüre kazandırılan örgütsel adalet kavrayabilmesi, iş görenlerin örgüt içerisindeki olayları, faaliyetleri ve kuralları adil bir çerçevede ele alması, yeni iş gören seçimi, performanslarının değerlendirilmesi, ödüllendirme, terfi, maaş gibi unsurlarla kendini göstermektedir (Greenberg, 1987: 41). İçerli (2010: 82) örgütsel adalet kavramını yöneticilerin örgüt ve iş görenlerle ilgili kararlarının iş görenler tarafından olumlu bir şekilde algılanması şeklinde açıklamaktadır. Altınkurt ve Yılmaz ise örgütsel adaleti iş görenlerin çalıştıkları örgütteki dağıtıma, işleyişe, etkileşimlere ilişkin algıları şeklinde tanımlamaktadır (Altınkurt ve Yılmaz, 2010: 470). İş görenler adil bir örgüt ortamında bulunmadıklarını hissettiklerinde motivasyonlarında ve performanslarında düşüş yaşanacaktır. $\mathrm{Bu}$ durum beraberinde işten uzaklaşma, saldırgan tutumlar gibi örgüt amaçlarını gerçekleştirmede zorlukların yașanmasına sebep olacaktır. Bir sonraki aşama ise stresin ve gerginliğin en üst seviyelerde yaşanması da beklenen bir durum olarak görülmektedir (İplik, 2009: 111). Eğitim kurumlarında da eğitimcilerin performans, verimlilik ve örgüte olan bağlılıklarının artışını gerçekleştirmenin yolu örgütsel adalete gereken önemi vermekten geçmektedir.

Günümüzde örgütsel adalet kavramının ortaya çıkış nedeni olarak üç unsurdan söz edilmektedir. $\mathrm{Bu}$ unsurlardan ilki adalet kavramının girilebilecek her ortamda insan ilişkilerinde ortaya çıkabilecek bir unsur olmasıdır. Bireyler çalıştıkları örgütlerde veya sosyal hayatlarında yaşadıkları kalabalık ortam içerisinde adalet algısına daima ihtiyaç duyacaklardır. Örgütsel adaletin günümüzde önemli bir kavram olarak görülmesine neden olan ikinci unsur da örgütlerin yönetim süreçlerinin tümünde adalet algısının belirleyici bir etmen olmasıdır. Bu hususa örnek olarak bir örgütte iş görenlere nasıl davranıldığı, iş görenlerin örgütlerine bağlılıkları, örgütlerine duydukları güven verilebilir (Şeșen, 2010: 82). Örgütsel adaletin günümüzde önemli bir kavram olarak görülmesine neden olan üçüncü unsur ise iş görenlerin çoğunluğunun eğitim düzeylerinin gitgide 
yükselmesi, bu nitelikli iş görenlerin iyi işler talep etmesi ve çalıştıkları örgütten kendilerine saygı ve samimiyet beklentileridir.

Örgütte bulunan iş görenler arasında adaletin sağlanması ve hak edene hakkının teslim edilmesi anlamına gelen örgütsel adalet kavramı kurumlarda uygulandığı sürece iş görenlerden istenen verimlilik en iyi düzeyde sağlanabilecektir. Aksi takdirde iş görenler çalıştıkları kurumda adaletsizlik olduğunu düşünüp, isteksiz çalışabilirler. Bu durum da örgüte olumsuz yansır. Örgütün belirlediği zamanda amaçlarına ve hedeflerine ulaşması da beklenemez, rakipleri ile yarışamayacak duruma gelir (Kılıç, 2013: 52).

Örgütsel adalet kavramının karmaşık yapısı, örgütte kararların nasıl alındığı, iş görenlerin yöneticileri tarafından ne tür muamelelere maruz kaldığı ve ne kadar ücret aldıkları gibi soruları akla getirmektedir. Bu soruların cevabı 4 boyut altında Greenberg tarafından incelenmiştir (Özkalp ve Kırel, 2013: 50). Örgütsel adaletin boyutları tarihsel süreçte de incelendiğinde Adams'ın Eşitlik Teorisine kadar sürecin uzadığı görülmektedir. Örgütsel adalet üç boyuttan oluşmaktadır:

-Dağıtım Adaleti: İş görenlerin örgütün sahip olduğu ücret, terfi, iş koşulları, ceza gibi usulleri ne kadar adil dağıttıklarını incelemektedir (Çolakoğlu ve diğerleri, 2021: 104). Çalışanlar bu hususta eșitsizlik olduğunu düşünürlerse bu olumsuz durum performanslarına da yansır (Eren, 2011: 21).

-Prosedür Adaleti: İş görenlerin ücret, terfi, ceza gibi usuller ile ilgili algılarına da prosedür adaleti denilmektedir. Leventhal prosedürlerin adil olmasını 6 koşula bağlamıștır. Bunlar aşağıdaki maddelerle ifade edilebilir (Cihangiroğlu ve Yılmaz, 2010: 202);

1- Dağıtım kanallarının tutarlı olması koșulu,

2- Dağıtım ve uygulama esnasında iş görenlere karşı ön yargı beslememek koşulu,

3- Bilgilerin doğruluğu ile ilgili kural,

4- Bazı kararların iş görenlerin itirazları neticesinde düzeltilebilmesi,

5- İş görenlerin kararlarını etkileyebilecek temsilcilerin seçilmesi,

6- Örgütte alınacak kararların iş görenlerin etik değerleri ile uyum sağlaması.

-Etkileşim Adaleti: Bies ve Moag tarafında ilk kez ortaya atılan bu kavram iş görenlerin kendilerine adil davranıldığını hissetmeleri için bireyler arası ilişkilerin dürüst olduğuna dair inançlarını ifade etmektedir (İplik, 2009: 113). Etkileşim adaleti kendi içerisinde kişilerarası ve bilgi adaleti olmak üzere iki grupta incelenmektedir (Battal, 2020: 2367). Kişilerarası adalet, üstlerin astlarına gösterdikleri saygı ve aldıkları kararları astların nasıl algıladıkları ile ilgili iken, bilgi adaleti, ücret, terfi gibi unsurlarla ilgili durumların nasıl algılandığı ile ilgilidir (Çolakoğlu vd., 2021: 105).

Örgütlerde yaşanabilecek olası bir adaletsizlik hali örgütün değerleri arasındaki uyumsuzluktan kaynaklanmakta ve örgütten ayrılmaya kadar devam etmektedir (Akram ve diğerleri, 2020: 120). Adil olmayan bir ortamda çalıştığını düşünen iş gören, motivasyonunu, iş tatminini ve örgüte bağlılığını kaybedecek iş yerinde çalışmaktan gurur duymamaya başlayacaktır.

\section{LITERATÜR TARAMASI}

3.1 Uzaktan Eğitim ile Yenilikçi Davranış Eğilimleri Arasındaki İlişkiyi Ele Alan Geçmiş Çalışmalar

Ogeh ve Chiemeka tarafından 2015 senesinde gerçekleştirilen çalışmada yenilikçi davranış ve uzaktan eğitim arasındaki ilişkiyi incelenmiştir. Elde edilen sonuca göre uzaktan eğitimin yenilikçi davranışı olumlu yönde etkilediği tespit edilmiştir (Ogeh ve Chiemeka, 2015: 146).

Söz konusu araştırma ve sosyal değişim kuramı ışığında bu çalışmada aşağıdaki hipotez geliştirilmiştir: 
“H1a: Üniversite öğrencilerinin uzaktan eğitime karşı tutumları yenilikçi davranış eğilimlerini etkiler."

\subsection{Uzaktan Eğitim ile Örgütsel Adalet Algısı Arasındaki İlişkiyi Ele Alan Geçmiş Çalışmalar}

Can (2020: 34) uzaktan eğitim döneminde yapılan sınavlarını hangi amaca dayanırsa dayansın öncelikle adaletli olarak yapılması gerektiğini belirtmiştir.

Bu açıklamalardan hareketle aşağıdaki hipotez geliştirilmiştir:

“H1b: Üniversite öğrencilerinin uzaktan eğitime karşı tutumları örgütsel adalet algısını etkiler."

3.3 Örgütsel Adalet Algısı ile Yenilikçi Davranış Eğilimleri Arasındaki İlişkiyi Ele Alan Geçmiş Çalışmalar

Örgütsel adaletin yenilikçi davranış üzerindeki etkisini inceleyen çalışmaların ortak özelliği bu iki değişken arasında anlamlı bir neden sonuç ilișkisi olduğunun ortaya konmasıdır. Örgütsel adalet algısı iyileştirildiğinde çalışanların yenilikçi davranışlarında artış gözlemlenebileceği ifade edilmiştir. Bu neticeler doğrultusunda aşağıdaki araştırma örnekleri verilmiștir;

Çelik tarafından yapılan çalışmada Antalya'da bulunan konaklama işletmelerinde çalışan 260 kişi ile bir anket uygulaması gerçekleștirilmiştir. Çalışmada örgütsel adalet, yenilikçi davranış ve kariyer memnuniyeti ilişkisi incelenmiștir. Yapılan analizlerin neticesine göre örgütsel adaletin yenilikçi davranışı etkilediği görülmüştür (Çelik, 2012: 111).

Jiun ve Jeng çalışması örgütsel adalet algısı, yenilikçi davranış ve örgütsel destek arasındaki ilişkiyi incelemek amacıyla The Landis firmasındaki 263 çalışan ile bir anket uygulaması gerçekleştirmiştir. Yapılan analizlerin neticesine göre örgütsel adalet algısı ile yenilikçi davranış arasında anlamlı bir ilişkinin olduğu tespit edilmiştir (Jiun ve Jeng, 2015: 120).

Ercan tarafından hazırlanan doktora tezinde İstanbul'daki sanayi ve hizmet sektörü firmalarının 525 çalışanı ile bir anket uygulaması gerçekleştirilmiştir. Çalışmada lider üye etkileşimi, yenilikçi davranış, işe adanmışlık, örgütsel özdeşleşme ve örgütsel adalet ilişkisinin tespit edilmesi amaçlanmış olup, yapılan analizlerin neticesinde yenilikçi davranış ile örgütsel adalet arasında anlamlı ilişkilerin olduğu, örgütsel adaletin söz konusu değişkenlerin tümünü etkilediği görülmüştür (Ercan, 2019: 114).

Nazir vd., tarafından yapılan çalışmada örgütsel adalet, yenilikçi davranış ve örgüt kültürü arasındaki ilişki incelenmiştir. Bu amaçla Pakistan'da bulunan bir imalat sektörü firmasının 367 çalışanı ile anket uygulaması gerçekleştirilmiştir. Yapılan analizlerin neticesinde örgütsel adaletin iş görenlerin yenilikçi davranışlarını etkilediği görülmüştür (Nazir vd., 2019: 1301).

Akram vd. tarafından yapılan çalışma Çin'de bulunan bir telekomünikasyon firmasının 345 çalışanına örgütsel adalet, bilgi paylaşımı ve yenilikçi davranış ilişkisini tespit amacıyla gerçekleştirilmiştir. Yapılan analizlerin neticesine göre örgütsel adalet ile yenilikçi davranış arasında anlamlı bir ilişkinin olduğu tespit edilmiștir (Akram ve diğerleri, 2020: 121).

Söz konusu geçmiş araştırmalar ışığında bu çalışmada aşağıdaki hipotezler geliştirilmiştir:

“H1c: Üniversite öğrencilerinin örgütsel adalet algısı yenilikçi davranış eğilimlerini etkiler."

H1d: Üniversite öğrencilerinin uzaktan eğitime karşı tutumları ve yenilikçi davranış eğilimleri ilişkisinde örgütsel adalet algısının aracılık rolü vardır

\section{ARAŞTIRMANIN YÖNTEMİ}

Bu çalışmada, COVID 19 sürecinde yaygınlaşan uzaktan eğitimin üniversite öğrencilerinin yenilikçi davranış eğilimleri ile ilişkisinde örgütsel adalet algısının aracılık etkisi incelenmiştir. Araştırmayı 
gerçekleştirmek amacıyla Bandırma Onyedi Eylül Üniversitesi Etik Kurulundan onay alınmıştır. Araştırmanın evrenini, Bandırma Onyedi Eylül Üniversitesi'nde öğrenim görmekte olan 15.721 öğrenci oluşturmaktadır. Örneklemini ise aynı üniversitede öğrenim görmekte olan 393 öğrenci olușturmaktadır.

Araştırmanın örneklemi hesaplanırken (Gürbüz ve Şahin, 2018: 318) tarafından geliştirilen örneklem hesaplama formülü kullanılmıştır. Bu formül kapsamında yapılan hesaplama neticesinde yaklaşık 375 kişilik bir örneklem evreni temsil edebilecek boyuttadır. Araştırma kapsamında örneklem büyüklüğü 393 öğrenci olduğundan evreni temsil edebilmesi açısından yeterlidir. Araştırma kapsamında, örneklem olarak ele alınan 393 öğrencinin sosyo-demografik özellikleri Tablo 1'de gösterilmiştir.

Tablo 1: Katılımcıların Demografik Özellikleri

\begin{tabular}{|c|c|c|c|}
\hline Değişken & & Frekans & Yüzde (\%) \\
\hline \multirow[t]{2}{*}{ Cinsiyet } & Kadın & 267 & 67.9 \\
\hline & Erkek & 126 & 32,1 \\
\hline \multirow[t]{4}{*}{ Yaş } & 17-20 & 246 & 62.6 \\
\hline & 21-24 & 100 & 25.4 \\
\hline & $25-28$ & 20 & 5.1 \\
\hline & 29 ve üzeri & 27 & 6.9 \\
\hline \multirow[t]{4}{*}{ Eğitim Durumu } & Ön lisans & 173 & 44.0 \\
\hline & Lisans & 186 & 47.3 \\
\hline & Yüksek Lisans & 26 & 6.6 \\
\hline & Doktora & 8 & 2.00 \\
\hline \multirow[t]{5}{*}{ Ailenizde yaşayan kişi sayısı } & 1 & 4 & 1.0 \\
\hline & 2 & 16 & 4.1 \\
\hline & 3 & 69 & 17.6 \\
\hline & 4 & 161 & 41.0 \\
\hline & 5 ve üzeri kişi & 143 & 36.4 \\
\hline \multirow[t]{2}{*}{ Bir işte çalışma durumu } & Evet & 75 & 19.1 \\
\hline & Hayır & 318 & 80.9 \\
\hline \multirow[t]{5}{*}{ Ailenizin Aylık Geliri } & $0-2.500 \mathrm{TL}$ & 97 & 24.7 \\
\hline & 2.501 TL- 5.000 TL & 197 & 50.1 \\
\hline & $5.001 \mathrm{TL}-7.000 \mathrm{TL}$ & 59 & 15.0 \\
\hline & 7.001 TL - 10.000 TL & 24 & 6.1 \\
\hline & 10.001 TL ve üzeri & 16 & 4.1 \\
\hline \multirow[t]{4}{*}{ Konut Sahiplik Durumu } & Kira & 128 & 32.6 \\
\hline & Kendi eviniz & 256 & 65.1 \\
\hline & Lojman & 3 & 0.8 \\
\hline & Diğer & 6 & 1.5 \\
\hline \multirow[t]{3}{*}{ Yaşadığınız Yerleşim } & İl & 172 & 43.8 \\
\hline & İlçe & 175 & 44.5 \\
\hline & Köy & 46 & 11.7 \\
\hline Toplam & & 393 & 100 \\
\hline
\end{tabular}

Tablo 1 incelendiğinde ankete katılanların çoğunluğunun 267 kişi ile kız öğrenci olduğu, 246 öğrencinin (\%62,6) 17-20 yaş arasında olduğu görülmüștür. Katılımcıların eğitim durumları açısından incelendiğinde 173 öğrenci (\%44) ön lisans, 186 öğrencinin $(\% 47,3)$ lisans seviyesinde eğitim görmekte olduğu tespit edilmiştir. Katılımcıların ailelerindeki kişi sayılarının genel itibariyle 
4 kişi ve üzeri olduğu, aylık gelirlerinin de genellikle 2.501 TL- 5.000 TL ile 197 öğrenci $(\% 50,1)$ olduğu tespit edilmiştir. Yine ankete katılan 75 öğrencinin $(19,1)$ bir işte çalıştığı ve oturdukları konutun sahiplik durumu açısından 256 öğrencinin $(\% 65,1)$ kendilerine ait evlerinin olduğu belirlenmiştir. Son olarak öğrencilerin yaşadıkları yerleşim yeri açısından tablo 1 incelendiğinde 172 öğrencinin $(\% 43,8)$ il merkezinde, 175 öğrencinin $(\% 44,5)$ ise ilçede yaşamakta olduğu tespit edilmiștir.

Araştırmada veriler anket yoluyla elde edilmiștir. Oluşturulan anket formu dört bölümden meydana gelmektedir. Birinci bölümde örgütsel adalet alglları ile ilgili sorular, ikinci bölümde uzaktan eğitime yönelik sorular, üçüncü bölümde ise yenilikçi davranış ile ilgili sorular yer almaktadır. Son bölümde ise katılımcıların demografik özelliklerinin tespitine yönelik sorular yer almaktadır.

Örgütsel adalet ölçeği olarak Niehoff ve Moorman (1993) tarafından geliştirilen ölçek kullanılmıştır (Niehoff ve Moorman, 1993: 5449. Bu ölçek Yıldırım (2017) tarafından "İş Doyumu ve Örgütsel Adalet Algısı" çalışmasından Türkçe'ye çevrilen 20 sorudan oluşmaktadır (Yıldırım, 2017: 261). Ölçeğin 3 alt boyutu bulunmaktadır. Bu alt boyutlar dağıtım adaleti, prosedür adaleti ve etkileşim adaletidir. Ankette dağıtım adaleti soruları (1-5) arası, prosedür adaleti soruları (6-11) arası ve etkileşim adaleti soruları (12-20) arası maddeleri kapsamaktadır. Alt boyutlar için ölçekte belirtilen Cronbach Alfa değerleri dağıtım adaleti için $(0,81)$, prosedür adaleti için $(0,89)$ ve etkileşim adaleti için $(0,95)$ şeklinde ifade edilmiştir.

Uzaktan eğitim ölçeği olarak Erdoğan, Bayram ve Deniz (2007) tarafından geliştirilen "Web Tabanlı Öğretim Tutum Ölçeği: Açıklayıcı ve Doğrulayıcı Faktör Analizi” çalışmasından yararlanılmıştır (Erdoğan ve diğerleri, 2007: 9). Ölçekte toplam 22 soru bulunmaktadır. Ölçeğin tamamına ilişkin Cronbach Alfa değeri 0,917 olarak tespit edilmiştir.

Yenilikçi davranış eğilimi için Çimen ve Yücel (2017) tarafından geliştirilen "Yenilikçi Davranış Ölçeği (YDÖ): Türk Kültürüne Uyarlama Çalışması”ndan yararlanılmştır (Çimen ve Yücel, 2017: 372). Ölçekte toplam 8 soru bulunmaktadır. Ölçeğin tamamına ilişkin Cronbach Alfa katsayısı 0,93 olarak tespit edilmiştir.

$\mathrm{Bu}$ ölçekler 5'li Likert skalasına göre derecelendirilmiştir (1=Kesinlikle katılmıyorum; 2=Katılmıyorum; 3=Fikrim yok; 4=Katılıyorum; 5= Kesinlikle katılıyorum). Verilerin analizinde frekans, normallik, güvenilirlik, koralasyon ve hiyerarşik regresyon analizlerinden yararlanılmıştır.

\section{ARAŞTIRMANIN BULGULARI}

\subsection{Güvenilirlik Analizleri}

Araştırmada, 20 ifadeden oluşan Örgütsel Adalet ölçeği, 22 sorudan oluşan Uzaktan eğitim ölçeği ve 7 sorudan oluşan yenilikçi davranış ölçeği kullanılmış olmakla birlikte soru listelerinin iç tutarlılığı ve güvenilirliğini ölçmek için Alfa (Alpha) katsayısı değerlerine bakılmıştır.

Araştırmada örgütsel adalet ölçeğinin Cronbach's Alpha güvenilirlik katsayısı 0,952 olarak, Uzaktan eğitim ölçeğinin Cronbach's Alpha güvenilirlik katsayısı 0,957 ve yenilikçi davranış ölçeğinin Cronbach's Alpha güvenilirlik katsayısı ise 0,858 olarak belirlenmiştir.

Alpha katsayısı 0 ile 1 arasında değișen değerler almaktadır. Bu değer 1'e yaklaştıkça ölçeğin güvenilirliği artmaktadır. Güvenilirliği ölçmek adına hesaplanan Alpha katsayısı 0,40-0,60 arasında bir değer alıyorsa ölçek düşük güvenilir, 0,60-0,80 arasında bir değer alıyorsa ölçek oldukça güvenilir ve 0,80-1,00 arasında bir değer alıyorsa ölçek yüksek güvenilir şeklinde ifade edilmiștir (Gürbüz ve Şahin, 2018: 319). Veriler doğrultusunda araştırma ölçeklerinin güvenilirliklerinin yüksek olduğu anlaşılmıştır.

\subsection{Normallik Testi}


Verilerin normal dağılımı, korelasyon ve regresyon analizlerinin uygulanabilmesi için önem arz etmektedir (Gürbüz ve Şahin, 2018: 288). Bu amaçla ölçeklerin normal dağılıp dağılmadığını belirlemek için normallik testi uygulanmıștır. Örgütsel adalet algısı için basıklık değeri ,079 ve çarpıklık değeri -,504 olarak hesaplanmıștır. Uzaktan eğitim için basıklık değeri -,575 ve çarpıklık değeri 490 olarak belirlenmiştir. Yenilikçi davranış eğilimleri içim basıklık değeri 1,103 ve çarpıklık değeri -,678 olarak tespit edilmiştir. Elde edilen sonuçlara göre üç ölçek için basıklık ve çarpıklık değerleri $-1,5$ ile $+1,5$ arasındadır. Bu sonuçlar verilerin normal dağıldığını göstermekte olup, daha sonraki aşamalarda korelasyon ve regresyon analizlerinin uygulanabileceğini ifade etmektedir.

\subsection{Korelasyon Analizi Bulguları}

Öğrencilerin örgütsel adalet algıları, uzaktan eğitime karşı tutumları ve yenilikçi davranış eğilimleri arasındaki ilişkiler korelasyon analizi ile araştırılmıştır.

Tablo 2: Korelasyon Analizi Bulguları

\begin{tabular}{|c|c|c|c|}
\hline Değişkenler & $\mathbf{1}$ & $\mathbf{2}$ & $\mathbf{3}$ \\
\hline Örgütsel Adalet & 1 & & \\
\hline Uzaktan Ĕgitim &, 000 & 1 & \\
&, $341^{* *}$ & & \\
\hline Yenilikçi Davranış &, 000 &, $169^{* *}$ & 1 \\
\hline
\end{tabular}

$\mathrm{N}: 393, \mathrm{p}^{*}<0.05, \mathrm{p}^{* *}<0.01$

Yapılan korelasyon analizinin sonucuna göre örgütsel adalet ile uzaktan eğitim arasında pozitif yönlü ve anlamlı bir ilişki $(r=0,341, p<0.05)$, örgütsel adalet ile yenilikçi davranış arasında pozitif yönlü ve anlamlı bir ilişki $(r=0,340, p<0.05)$ ve uzaktan eğitim ile yenilikçi davranış arasında pozitif yönlü ve anlamlı bir ilişki ( $\mathrm{r}=0,169, \mathrm{p}<0.05)$ olduğu görülmüștür.

\section{4. Üniversite Öğrencilerinde Uzaktan Eğitime Karşı Tutumlarının Yenilikçi Davranış Üzerindeki Etkisinde Örgütsel Adalet Algısının Aracılık Etkisinin Hiyerarşik Regresyon Analizi İle Tespiti}

Aracı değişken bağımlı ve bağımsız değişkenler arasında yer alır ve bu iki değişken arasında bağlantı kurar (Gürbüz ve Şahin, 2018: 260). Bu aracılık modeli dört aşamadan meydana gelmektedir. 
Şekil 1. Temel Aracılık Modeli

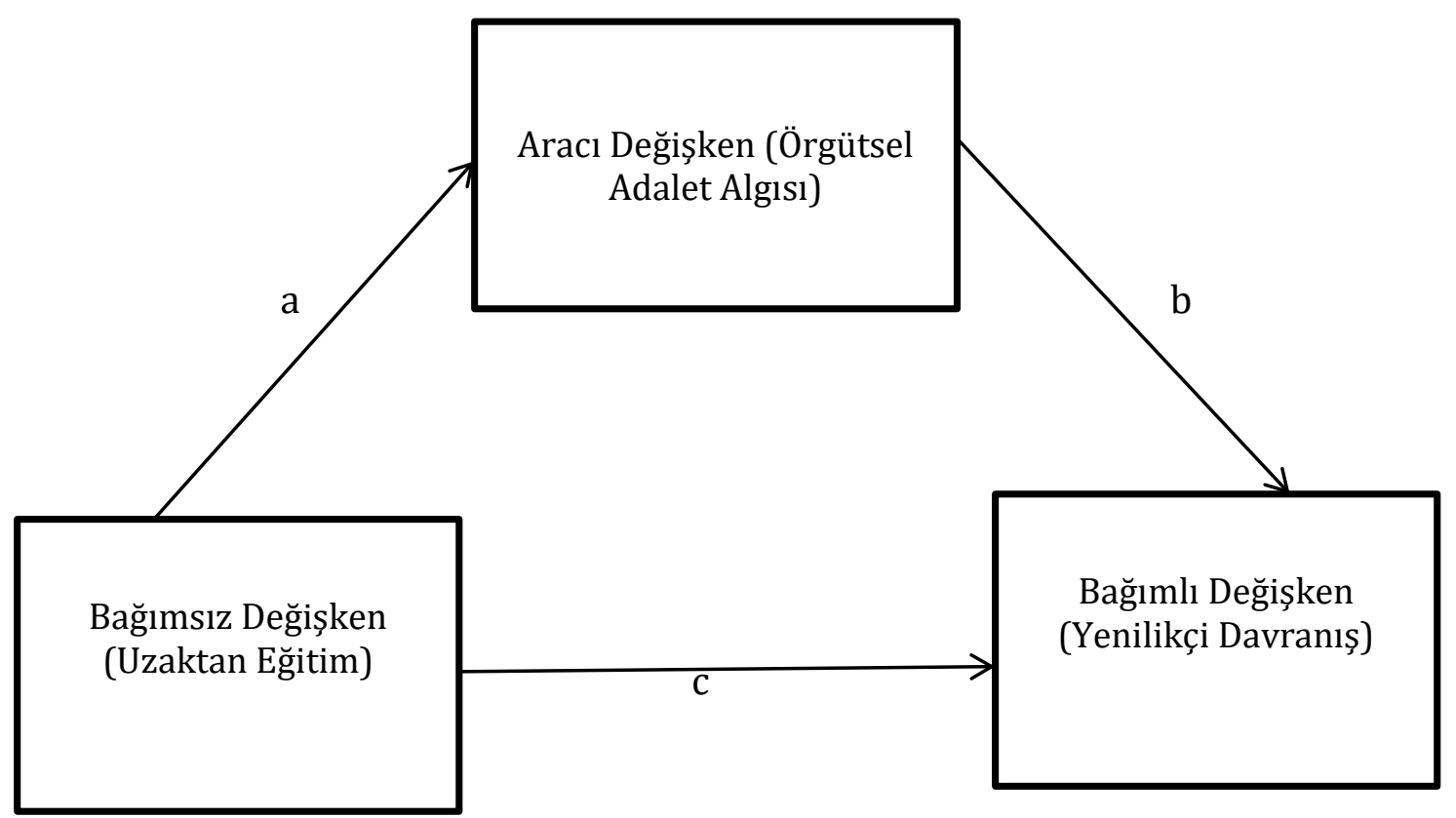

Tablo 3: Değișkenler Arasında Ortaya Çıkan İlișkiler

\begin{tabular}{|c|c|c|c|c|c|c|c|}
\hline $\begin{array}{c}\text { Bağımlı } \\
\text { D. }\end{array}$ & Bağımsız D. & $\mathbf{R}$ & $\mathbf{R}^{2}$ & D. $\mathbf{R}^{2}$ & F & B & Sig. \\
\hline 1.YD & UE &, 169 &, 028 &, 026 & 11,446 &, 169 &, 001 \\
\hline 2.0̈A & UE &, 341 &, 116 &, 114 & 51,455 &, 341 &, 000 \\
\hline 3.YD & ÖA &, 340 &, 116 &, 113 & 51,176 &, 340 &, 000 \\
\hline
\end{tabular}

YD: Yenilikçi davranış, ÖA: Örgütsel adalet, UE: Uzaktan eğitim, D. R² : Düzeltilmiş R ${ }^{2}$

Tablo 3'teki basit regresyon analizlerinin birinci adımının sonucu incelendiğinde üniversite öğrencilerinde uzaktan eğitime karşı tutumlarının yenilikçi davranış eğilimi üzerinde anlamlı bir etkisinin olduğu görülmüștür $(\mathrm{p}<0,05)$. Bunun sonucu olarak $\mathrm{H}_{1 a}$ hipotezi kabul edilmiștir.

Regresyon analizinin ikinci adımının sonucu incelendiğinde üniversite öğrencilerinde uzaktan eğitime karşı tutumlarının örgütsel adalet üzerinde anlamlı bir etkisinin olduğu görülmüştür. Analiz sonuçlarına dayalı olarak $\mathrm{H}_{1}$ b hipotezi kabul edilmiştir.

Regresyon analizinin üçüncü adımının sonucu incelendiğinde üniversite öğrencilerinde örgütsel adalet algısının yenilikçi davranış üzerinde anlamlı bir etkisinin olduğu görülmüştür. Bu sonuçlara dayalı olarak $\mathrm{H}_{1 \mathrm{c}}$ hipotezi kabul edilmiştir. 
Tablo 4: Üniversite Öğrencilerinde Uzaktan Eğitime Karşı Tutumlarının Yenilikçi Davranış Eğilimleri Üzerindeki Etkisinde Örgütsel Adalet Algısının Aracılık Rolünün Hiyerarşik Regresyon Analizi İle Testi

\begin{tabular}{|c|c|c|c|c|c|c|}
\hline $\begin{array}{c}\text { Bağımlı } \\
\text { Değişken }\end{array}$ & $\begin{array}{l}\text { Bağımsız } \\
\text { Değișken }\end{array}$ & B & Std. Hata & $\beta$ & $t$ & $\mathbf{p}$ \\
\hline \multirow[t]{2}{*}{ YD } & ÖA & ,288 & ,046 & ,320 & 6,327 & ,000 \\
\hline & UE & 046 & 039 & 060 & 1,178 & 240 \\
\hline \multicolumn{7}{|l|}{$\mathbf{F}=26,307$} \\
\hline \multicolumn{7}{|l|}{$\mathbf{R}^{2}=, 119$} \\
\hline \multicolumn{7}{|c|}{ Düzeltilmiş $\mathbf{R}^{2}=, 114$} \\
\hline \multicolumn{7}{|c|}{ Tahmini Std. Hata $=, 71840$} \\
\hline \multicolumn{7}{|c|}{ ANOVA (Anlamlılık) $=, 000$} \\
\hline
\end{tabular}

Tablo 4'te çoklu regresyon modelinin katsayıları ve standardize katsayılar, çoklu regresyon modelinde bağımlı değişkenleri açıklamada anlamlı katkıları olan bağımsız değişkenler gösterilmiştir. Tam aracılık durumunda, aracı değişken modele eklendiğinde bağımlı ya da bağımsız değişken arasındaki ilişkinin oldukça zayıflaması ya da istatistiksel olarak anlamsız duruma gelmesi beklenir. Tablo 4'te belirtilen aracı regresyon analizinin dördüncü adımında uzaktan eğitim ile yenilikçi davranış arasındaki ilişki anlamsız hale gelmiştir. Elde edilen bu sonuca göre tam aracılık etkisi bulunmuştur. Hiyerarşik regresyon analizi sonucuna göre $\mathrm{H} 1_{\mathrm{d}}$ hipotezi kabul edilmiştir.

\section{SONUÇ, TARTIŞMA VE ÖNERILER}

Çalışmada gerçekleștirilen hiyerarşik regresyon analizinin birinci adımındaki neticeye göre, üniversite öğrencilerinin uzaktan eğitime karşı tutumlarının yenilikçi davranışı etkilediği tespit edilmiştir. Elde edilen bu sonuç; Tura ve Akbaş tarafından (2021) yapılan çalışmanın sonuçları ile örtüşmekte olup, iki değişken arasındaki nedensellik ilișkisini onaylamaktadır (Tura ve Akbaş, 2021: 20). Hiyerarşik regresyon analizinin ikinci adımından elde edilen sonuca göre uzaktan eğitime karşı tutumun örgütsel adalet algısını etkilediği tespit edilmiştir. Elde edilen bu sonuç, Can (2020) çalışmasının sonuçları ile benzerlik göstermekte olup, iki değişken arasındaki nedensellik ilişkisini onaylamaktadır (Can, 2020: 41). Hiyerarşik regresyon analizinin üçüncü Adımından elde edilen sonuca göre örgütsel adalet algısının yenilikçi davranışı etkilediği görülmüştür. Elde edilen bu sonuç, Suliman (2013) tarafından yapılan çalışmanın sonuçları ile benzerlik göstermekte olup, iki değişken arasındaki nedensellik ilişkisini onaylamaktadır (Suliman, 2013: 950). Hiyerarşik regresyon analizinin dördüncü ve son adımında ise öğrencilerin uzaktan eğitime karşı tutumları ve yenilikçi davranış eğilimleri ilişkisinde örgütsel adalet algısının aracılık rolünün olduğu görülmüştür. Örgütsel adalet algısı dördüncü adımda devreye girdiğinde yenilikçi davranış eğilimleri ve uzaktan eğitime karşı tutum arasındaki ilişkiyi anlamsız kılmaktadır. Örgütsel adalet algısının önemi eğitim süreçleri açısından da ortaya çıkmıştır. Örgütsel adalet algısında olumsuzluk 
söz konusu olduğunda teknik imkanların anlamsız kaldığı ve yenilikçi davranışlar geliştirmenin zorlaşacağı görülmüştür.

Pandemi döneminde uzaktan eğitim hizmeti sunan üniversitelerin öğrencilerin ihtiyaçlarını karşılarken, elektronik araçları kullanan kişilere hızlı geri bildirimlerle bireyselleştirilmiş eğitim sistemini sunmaları gerekmektedir (Harry ve Perraton, 2003: 28). Üniversitelerin kendi içerisinde yaşadığı sıkıntılar bazı durumlarda öğrenci ve kurumun karşı karşıya kalmasına neden olmaktadır. Uzaktan eğitim sürecinde etkileşimin yeterli olmaması, öğrencilerin adil bir eğitim-öğretim süreci yaşamamaları yenilikçi davranışların gelişmesini engelleyecektir. . Bu sebeple adil bir uzaktan eğitim sisteminin sağlanabilmesi ve geliştirilebilmesi için uzaktan eğitim hizmetinin öğrencilere zamanında verilmesi, ders dıșı online sosyal faaliyet imkanlarının sağlanması, iletişim alt yapısının online eğitim için yeterli olması gereklidir. İş hayatında olan öğrenciler için zamanı etkin kullanmaları ve uygun olduklarında eğitim imkânlarından faydalanabilmeleri için firsat tanınmalıdır. Öğretim elemanlarının teknolojiyi etkin kullanabilmeleri için eğitim desteği sağlanmalıdır. Öğrenci merkezli ders içerikleri hazırlanması, eğitimde fırsat eşitliğine imkân tanıyacaktır. Öğrencilerin yaşayabileceği üniversite merkezli teknik aksaklıklar giderilmelidir. Her öğrencinin bilgisayar, tablet vb. teknik aksama sahip olamayacağının bilincinde olunmalıdır.

Öğrencilerin uzaktan eğitim ile öğrenmekte güçlük yaşadığı dersler için uygun ve verimli teknikler, uygulanabilmelidir. Ders materyallerinin geliştirilebilmesi yararlı olacaktır. Sanal sınıf ortamlarında derse öğrenci katılımını ve interaktif etkileşimi daha etkin kılacak ortamlar özendirilmelidir.

Öğrencilerin sınav notları adalet algısını sarsmamalıdır. Uzaktan eğitim esnasında öğrencilerle karşılıklı etkileşim ortamı sağlanırken adaletsizlik algısı yaratacak davranışlardan sakınılmalıdır. Uzaktan eğitim süreçlerinde adalet algısına uygun düzenlemeler geliştirilmelidir.

$\mathrm{Bu}$ çalışma Bandırma Onyedi Eylül Üniversitesi'nde öğrenim görmekte olan 393 öğrenci ile gerçekleştirilmiştir. Sonuçlar araştırmanın örneklemi ile sınırlıdır. Daha geniş bir örneklem çerçevesinde, farklı üniversitelerde öğrenim görmekte olan öğrencilerin de fikrini alarak yapılacak çalışmalar karşılaştırma ve genelleme açısından yarar sağlayacaktır. 


\section{KAYNAKÇA}

Akça, F. ve Şakar, Z. (2017). Öğretmen adaylarının bireysel yenilikçilik düzeylerinin incelenmesi. Ankara: Pegem Akademi Yayınları.

Akram, T., Lei, S., Haider, M. ve Hussain, S. (2020). The impact of organizational justice on employee innovative work behaviour: Mediating role of knowledge sharing. Journal of Innovation and Knowledge, 5(2020), 117-129.

Altınkurt, Y. ve Yılmaz, K. (2010). Değerlere göre yönetim ve örgütsel adalet ilişkisinin ortaöğretim okulu öğretmenlerinin algllarına göre incelenmesi. Kuram ve Uygulamada Eğitim Yönetimi, $4(4), 463-485$.

Amabile, T. M. (1988). A model of creativity and innovation in organizations. Research in Organizational Behaviour, 10, 123-167.

Bakioğlu, B. ve Çevik, M. (2020). Covid-19 pandemisi sürecinde fen bilimleri öğretmenlerinin uzaktan eğitime ilişkin görüşleri. Turkish Studies Journal, 15(4), 109-129.

Banar, K. ve Fırat, M. (2015). Bütüncül bir bakıştan açık ve uzaktan eğitim. Yeğitek Yenilik ve Eğitim Teknolojileri, 12, 18-21.

Battal, F. (2020). Örgütsel adalet ve örgütsel bağlllık ilişkisinde örgütsel özdeşleşmenin rolü: Üniversite çalışanları üzerine bir örnek. OPUS Uluslararası Toplum Araştırmaları Dergisi, 10(15), 2363-2393.

Bayram, M., Peker A.T, Aka S.T. ve Vural M., (2019). Üniversite öğrencilerinin uzaktan eğitim dersine karşı tutumlarının incelenmesi. Gaziantep Üniversitesi Spor Bilimleri Dergisi, 4(3), 330-345.

Can, E. (2020). Coronavirus (Covid-19) pandemisi ve pedagojik yansımaları: Türkiye'de açık ve uzaktan eğitim uygulamaları. Açıköğretim Uygulamaları ve Araştırmaları Dergisi, 6(2), 11-53.

Cihangiroğlu, N. ve Yılmaz, A. (2010). Çalışanların örgütsel adalet algısının örgütler için önemi. Sosyal ve Ekonomik Araştırmalar Dergisi, 13(19), 195-213.

Çelik, V. (2012). Okul kültürü ve yönetimi. Ankara: Pegem Akademi Yayınevi.

Çimen, İ. ve Yücel, C. (2017). Innovative behavior scale (IWB): Adaptation to Turkish culture. Cumhuriyet International Journal of Education, 6(3), 365-381.

Çolakoğlu, N., Dikili, E. ve Aslan, M. (2021). Örgütsel adaletin örgütsel bağlılığı etkisi. Journal of Life Economics, 8(1), 101-109.

Damanpour, F. (1991). Organizational innovation: A meta-analysis of effects of determinants and moderators. Academy of Management Journal, 34, 555-590.

Demircioğlu, T., Konokman, G., Y. ve Akay, C. (2016). Eğitim fakültesi öğretim elemanlarının yenilikçilik düzeylerinin Avrupa Birliği hayat boyu öğrenme projelerine yönelik tutumlarına etkisi. Elektronik Sosyal Bilimler Dergisi, 15(59), 1120-1137.

Dikmen, S. ve Bahçeci, F. (2020). Covid-19 pandemisi sürecinde yükseköğretim kurumlarının uzaktan eğitime yönelik stratejileri: Fırat Üniversitesi örneği, Turkish Journal of Educational Studies, 7(2), 78-98.

Durak, G., Çankaya, S. ve İzmirli, S. (2020). Covid-19 pandemi döneminde Türkiye'deki üniversitelerin uzaktan eğitim sistemlerinin incelenmesi. Necatibey Eğitim Fakültesi Elektronik Fen ve Matematik Eğitimi Dergisi, 14(1), 787-809. 
Ercan, S. (2019). Lider-üye etkileşimi, yenilikçi iş davranışı, işe adanmışlık, örgütsel özdeşleşme ilişkisinde örgütsel adaletin aracı rolü. (Yayımlanmamış doktora tezi). Maltepe Üniversitesi Sosyal Bilimler Enstitüsü, İstanbul.

Erdoğan, Y., Bayram, S. ve Deniz, L. (2007). Web tabanlı öğretim tutum ölçeği: Açıklayıcı ve doğrulayıcı faktör analizi çalışması. Uluslararası İnsan Bilimleri Dergisi, 4(2), 1-14.

Eren, E. (2011). Yönetim ve organizasyon çağdaş ve küresel yaklaşımlar. İstanbul: Beta Basım Yayın Dağıtım.

Genç, M.F. ve Gümrükçüoğlu, S. (2020). Koronavirüs (Covid-19) sürecinde ilâhiyat fakültesi öğrencilerinin uzaktan eğitime bakışları. Turkish Studies, 15(4), 403-422.

Goswami, S. ve Mathew, M. (2005). Definition of innovation revisited: An emprical study on Indian information technology industry. International Journal of Innovation Management, 9(3), 371383.

Greenberg, J. (1987). Reactions to procedural injustice in payment distributions: Do the means justify the ends? Journal of Applied Psychology, 72(1), 1-55.

Gürbüz, S. ve Şahin, F. (2018). Sosyal bilimlerde araştırma yöntemleri. Ankara: Seçkin Yayıncılık.

Harry, K. ve Perraton, H. (2003). Open and distance learning for the new society. In Higher education through open and distance learning. New York: Routledge.

Hasırcı, I. (2020). Örgüt kültürünün inovatif davranış eğilimleri ile ilișkisinde öz yeterlilik algısının aracılık rolü ve bir uygulama. (Yüksek lisans tezi). Bandırma Onyedi Eylül Üniversitesi Sosyal Bilimler Enstitüsü, Bandırma.

Hebebci, M. T., Bertiz, Y. ve Alan, S. (2020). Investigation of views of students and teachers on distance education practices during the Coronavirus (COVID-19) pandemic. International Journal of Technology in Education and Science (IJTES), 4(4), 267-282.

İçerli, L. (2010). Örgütsel adalet: Kuramsal bir yaklaşım. Girişimcilik ve Kalkınma Dergisi, 5(1), 6792.

İplik, F.N. (2009). Algılanan örgütsel adaletin örgütsel vatandaşlık davranışları üzerindeki etkisinin belirlenmesine yönelik süpermarket çalıșanları üzerinde bir araștırma: Adana ili örneği. Dumlupınar Üniversitesi Sosyal Bilimler Dergisi, (25), 107-118.

İşman, A. (2011). Uzaktan eğitim. Ankara: Pegem Akademi Yayınları.

Jiun-Lan, H. S. U. ve Jeng-Hwan, W. (2015). Exploring the effects of organizational justice on employees innovative behavior in hospitality industry from the aspect of organizational support. Revista De Cercetare Si Interventie Sociala, 49, 113-126.

Karadağ, E. ve Yücel, C. (2020). Yeni tip Koronavirüs pandemisi döneminde üniversitelerde uzaktan eğitim: Lisans öğrencileri kapsamında bir değerlendirme çalışması, Yükseköğretim Dergisi, 10(2), 181-192.

Keskin, M. ve Özer, D. (2020). COVID-19 sürecinde öğrencilerin web tabanlı uzaktan eğitime yönelik geri bildirimlerinin değerlendirilmesi. İzmir Kâtip Çelebi Üniversitesi Sağlık Bilimleri Fakültesi Dergisi, 5(2), 59-67.

Kılıç, S. (2013). İnovasyon ve inovasyon yönetimi. Ankara: Seçkin Yayıncılık.

Koç, A. (2015). E-Öğrenme ve Türk eğitim sistemindeki yeri. Sosyal Bilimler Dergisi, (3), 44-57. 
Kurnaz, E. ve Serçemeli, M. (2020). Covid 19 pandemi döneminde akademisyenlerin uzaktan eğitim ve uzaktan muhasebe eğitimine yönelik bakış açıları üzerine bir araştırma. Uluslararası Sosyal Bilimler Akademi Dergisi, 2(3), 263-288.

Kürtüncü, M. ve Kurt, A. (2020). Covid 19 pandemisi döneminde hemşirelik öğrencilerinin uzaktan eğitim konusunda yaşadıkları sorunlar. Avrasya Sosyal ve Ekonomi Araştırmaları Dergisi, $7(5), 66-77$.

Nazir, S., Shafi, A., Atıf, M., Qun, W. ve Abdullah, S. (2019). How organization justice and perceived organizational support facilitate employees, innovative behavior at work. Employee Relations, 41(6), 1288-1311.

Negüs, F. (2016). Örgün ve uzaktan eğitim lisans öğrencilerinin teknoloji kabulüne ilişkin tutumları üzerine bir araştırma. İstanbul Journal of Social Sciences, 14, 1-12.

Niehoff, B. P ve Moorman, R. H. (1993). Justice as a mediator of the relationship between methods of monitoring and organizational Citizenship Behavior. Academy of Management Journal, 36(3), 527-556.

Odabaş, H. (2003). Internet tabanlı uzaktan eğitim ve bilgi ve belge yönetimi. Türk Kütüphaneciliği, 17(1), 22-36.

Ogeh, W. M. ve Chiemeka N. (2015). Creativity and innovation in open and distance education: A paradigm for human development in the 21st century for nation-building in Nigeria. Journal of Education and Practice, 6(4), 143-147.

Özbay, Ö. (2015). Dünyada ve Türkiye'de uzaktan eğitimin güncel durumu. INES Journal, 2(5), 376394

Özçer, N. (2005). Yönetimde yaratıcılık ve yenilikçilik. İstanbul: Rota Yayınları.

Özkalp, E. ve Kırel, Ç. (2013). Örgütsel davranış. Bursa: Ekin Basım.

Plessis, M. (2007). The role of knowledge management in innovation. Journal of Knowledge Management, 11(4), 20-29.

Schlechty, P. C. (2014). Okulu yeniden kurmak. Ankara: Nobel Yayınları.

Senge, P. (2000). Beşinci disiplin. İstanbul: Yapı Kredi Yayınları.

Suliman, A. (2013). Organizational justice and innovation in the workplace: The case of the UAE. Journal of Management Development, 32(9), 945-959.

Sweeney, J. E. (2016). Innovation in the school context: An exploratory study. (Yayınlanmamış doktora tezi). Faculties of the University of Pennsylvania, Pennsylvania.

Şentürk, F. K., Durak, M., Yılmaz, E., Kaban, T., Kök, N. ve Baş, A. (2016). Dönüşümcü ve etkileşimci liderlik tarzlarının bireysel yenilikçiliğe etkisini belirlemeye yönelik bir araştırma. Mehmet Akif Ersoy Üniversitesi Sosyal Bilimler Enstitüsü Dergisi, 8(17), 173-198.

Şeşen, H. (2010). Adalet algısının tükenmişliğe etkisi: İş tatmininin aracı değişken rolünün yapısal eşitlik modeli ile testi. Savunma Bilimleri Dergisi, 9(2), 67-90.

Thurlings, M., Evers, A. T. ve Vermeulen, M. (2015). Toward a model of explaining teachers' innovative behavior: a literature review. Review of Educational Research, 85(3), 430-471.

Tura, B. ve Akbaşlı, S. (2021). Öğretmen yenilikçiliğini etkileyen faktörler. Uluslararası Ticaret ve Ekonomi Araştırmaları Dergisi, 1, 15-28. 
Yıldırım, F. (2007). İş doyumu ile örgütsel adalet ilişkisi. Ankara Üniversitesi SBF Dergisi, 62(1), 253-278. 


\section{EXTENDED ABSTRACT}

\section{The Mediating Role Of Organizational Justice Perception In The Relationship Of Distance Learning With Innovative Behaviour Trends Of University Students That Have Become Widespread In The Covid - 19 Process: A Research}

\section{Introduction}

Distance education is the provision of communication and interaction through specially prepared environments in cases where it is not possible to carry out activities in the classroom due to the limitations of face-to-face education. Distance education has many advantages for students in terms of sociological, psychological, financial and cultural aspects as well as disadvantages. It is among the advantages of creating an educational environment without the problem of space, being economical and enriching educational activities with technology. The disadvantages of the distance education system are the need for time for the development of the distance education system, the inability of the students to reach sufficient information in the use of the computer and the programs, the system failures, the problems experienced with the use of devices such as computers, phones and tablets for a long time. In the COVID-19 process, the disadvantages of distance education have been effective in terms of students' being able to acquire professional knowledge and think critically. It is desirable that university students have a positive attitude towards distance education and that this situation positively affects their innovative behavior tendencies. Research has been conducted on the fact that individuals' perceptions of justice can have significant effects on many of their attitudes and behaviors. In the presence of factors that negatively affect the perception of justice, it is expected that attitudes and behaviors will also be negatively affected. Systems that will support the innovative behavior of students, who are defined as the future of the country, cannot be expected to be successful in negative justice perception environments. The main purpose of this study is to determine the effects on students' attitudes and innovative behavior tendencies towards distance education, which has been put into practice due to the global epidemic. The main reason for the study is the need for the development of innovative behaviors of young people in the development of the country. The role of attitudes towards the applied education models in terms of meeting this need is undeniable. The importance of the study is that it is one of the rare studies investigating the effect of attitudes towards the distance education model and the perception of justice on innovative behaviors together, due to the fact that face-to-face education had to be suspended.

\section{Data Set and Method}

In this study, the mediating effect of organizational justice perception in the relationship of distance education, which became widespread during the COVID 19 process, with innovative behavior tendencies of university students was examined. In order to carry out the research, approval was obtained from the Ethics Committee of Bandırma Onyedi Eylül University. The population of the research consists of 15,721 students studying at Bandırma Onyedi Eylül University. The sample consists of 393 students studying at the same university.

While calculating the sample of the research, the sample calculation formula developed by was used. As a result of the calculation made within the scope of this formula, a sample of approximately 375 people is large enough to represent the universe. As the sample size of the research is 393 students, it is sufficient to represent the universe.

\section{Empirical Findings}

According to the result of the first step of the hierarchical regression analysis carried out in the study, it has been determined that the attitudes of university students towards distance education affect innovative behavior. According to the result obtained from the second step of the hierarchical 
regression analysis, it was determined that the attitude towards distance education affects the perception of organizational justice. When the perception of organizational justice comes into play in the fourth step, it renders the relationship between innovative behavior tendencies and attitudes towards distance education meaningless. The importance of organizational justice perception has also emerged in terms of educational processes. It has been seen that technical possibilities are meaningless when the perception of organizational justice is negative and it will be difficult to develop innovative behaviors.

\section{Discussion and Conclusion}

Universities that provide distance education services during the pandemic period, while meeting the needs of students, should offer an individualized education system with quick feedback to those who use electronic tools. The problems experienced by universities in some cases cause students and institutions to face each other. Insufficient interaction in the distance education process and the fact that students do not experience a fair education-teaching process will prevent the development of innovative behaviors. . For this reason, in order to provide and develop a fair distance education system, it is necessary to provide distance education services to students on time, to provide extracurricular online social activities, and to have sufficient communication infrastructure for online education. Students who are in business life should be given the opportunity to use their time effectively and to benefit from educational opportunities when appropriate. Educational support should be provided for instructors to use technology effectively. The preparation of student-centered course contents will allow equal opportunities in education. University-based technical problems that students may experience should be eliminated. Each student's computer, tablet, etc. It should be noted that there will be no technical problems.

Appropriate and efficient techniques should be applied for the courses that students have difficulty in learning with distance education. Developing course materials would be helpful. In virtual classroom environments, environments that will make student participation and interactive interaction more effective should be encouraged.

Students' exam grades should not shake the perception of justice. While providing an environment of mutual interaction with students during distance education, behaviors that will create a perception of injustice should be avoided. Regulations in accordance with the perception of justice should be developed in distance education processes. 